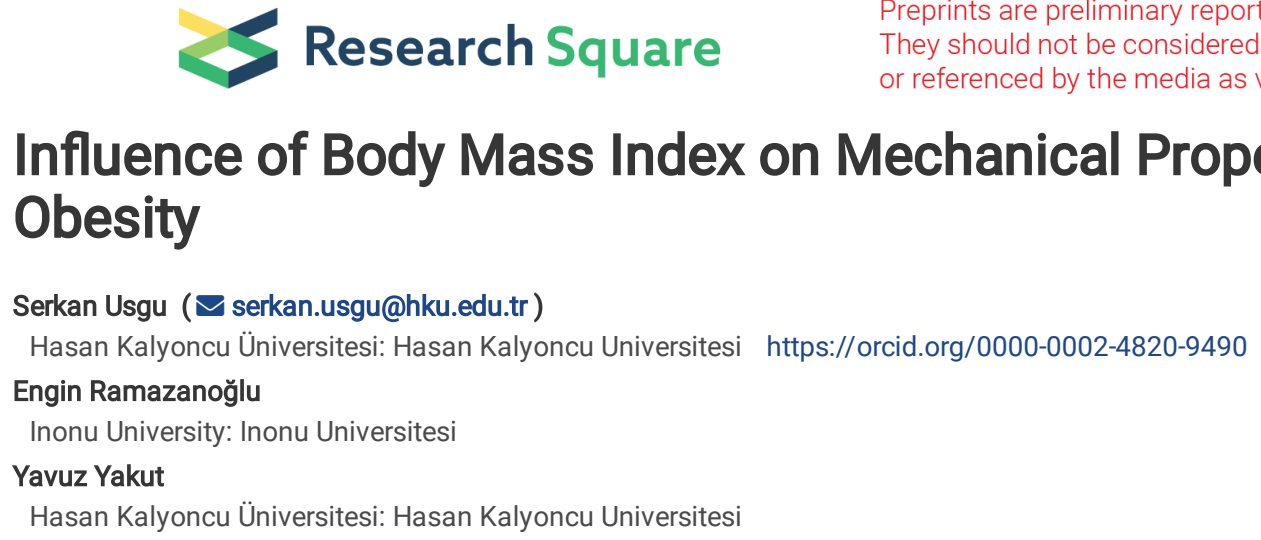

Serkan Usgu ( $\sim$ serkan.usgu@hku.edu.tr)

Hasan Kalyoncu Üniversitesi: Hasan Kalyoncu Universitesi https://orcid.org/0000-0002-4820-9490

Engin Ramazanoğlu

Inonu University: Inonu Universitesi

Yavuz Yakut

Hasan Kalyoncu Üniversitesi: Hasan Kalyoncu Universitesi

\title{
Influence of Body Mass Index on Mechanical Properties in People With Obesity
}

\section{Research article}

Keywords: Body mass index, tone, stiffness, elasticity, obesity

Posted Date: May 10th, 2021

DOI: https://doi.org/10.21203/rs.3.rs-383093/v1

License: () (i) This work is licensed under a Creative Commons Attribution 4.0 International License. Read Full License 


\section{Abstract}

Background: The study was to determine influence of body mass index on muscular mechanical properties in people with obesity.

Methods: A total of 300 individuals (mean age: $27.31 \pm 7.21$ years) were participated. The participants were assigned in groups base on BMI classification (Group 1 (BMl=18.50-24.99 kg/m²), Group $2\left(\mathrm{BMl}=25.00-29.99 \mathrm{~kg} / \mathrm{m}^{2}\right)$, and Group $3\left(\mathrm{BMI} \geq 30 \mathrm{~kg} / \mathrm{m}^{2}\right)$ ). The biceps brachii (BB), biceps femoris $(\mathrm{BF})$ were measured bilaterally using the "MyotonPRO" device.

Results: All mechanical properties of the right and left BB muscle, left BF tone and stiffness were found significantly difference between groups ( $<<0.05$ ). The bilateral BB tone in Group 3 was lower than the other two groups. The right BB stiffness of Group 2 was found to be higher compared to the other two groups $(p<0.05)$. While the right and left BB elasticity was similar in Groups 2 and 3 , it was lower compared to Group 1 ( $p<0.05)$. The left BF tone and stiffness of Group 3 were found to be significantly higher than Groups 1 and $2(p<0.05)$.

The right BB tone showed a weak negative correlation with BMI in females, and for left side in males. A weak positive correlation was found between the right and left BB elasticity and BMI in males and females. The left-right BF tone and left BF stiffness showed a weak positive correlation in males.

Conclusions: The bilateral BB tone and elasticity decreased, and the left BF stiffness increased as BMI increased. Different mechanical properties were observed in sex comparasion base on BMI clasification. The BB and BF mechanical properties were affected more in males than females.

\section{Plain English Summary}

Obesity is closely related to fat tissue, and it may have direct or indirect effects on physical activity and the musculoskeletal system This study was conducted to determine influence of body mass index on muscular mechanical properties in people with obesity. Our findings showed fat tissue and muscular mechanical properties had weak relation. The muscle firmless and elasticity decreased as fat tissue increased and the mechanical properties were affected more in males than females. The muscular actions and efficiency can adopt to inactivity. Therefore, our study demonstrated the obesity or higher BMI lead to the human body for developing different muscular adaption. The upper and lower extremity muscles acting differently for daily living activities or functions. The increased mechanical load in lower leg cause to rising stiffness of muscles. The upper extremity muscles, which lacks mechanical loading, may adversely affected.

\section{Introduction}

Obesity is a significant health problem that is gradually increasing. It can be defined as excessive fat accumulation in a way that can disrupt health, and it predisposes to chronic diseases (1). The calculation of body mass index (BMI) is the simplest indicator of an increase in adipose tissue in the body and the frequently used method (2). According to BMl, individuals are evaluated as underweight $\left(<18.5 \mathrm{~kg} / \mathrm{m}^{2}\right)$, normal $\left(18.5-24.9 \mathrm{~kg} / \mathrm{m}^{2}\right)$, overweight $(25-29.9$ $\left.\mathrm{kg} / \mathrm{m}^{2}\right)$, first-degree obese (30-34.9 kg/m²), second-degree obese (35-39.9 kg/m²), and third-degree morbidly obese $\left(\geq 40 \mathrm{~kg} / \mathrm{m}^{2}\right)(3)$. A decrease or increase in BMI may be a factor in the formation of chronic diseases (4).

Obesity is closely related to adipose tissue, and it may have direct or indirect effects on physical activity and the musculoskeletal system (5). While the relationship of obesity with cardiovascular diseases and type 2 diabetes draws attention, its effects on the musculoskeletal system are less questioned. Disorders that can affect bone health, such as osteoarthritis or osteoporosis, which threaten joint health due to overload, are the most well-known. There are few studies on the effects of increased BMI on the mechanical properties of muscles or the methods evaluated these properties (6).

Non-invasive elastography, ultrasonographic or myotonometric evaluations are used to evaluate the mechanical properties of muscles (7-9). Myotonometric evaluation which has recently become popular and offers the advantage of use in clinics. The device probe ( $3 \mathrm{~mm}$ in diameter) is placed vertically on the muscle and skin, and the stroke of the probe $(0.18 \mathrm{~N})$ causing the oscillations obtained by compressing the subcutaneous tissues $(9,10)$. The sternocleidomastoid (SCM) and upper trapezius (UT) muscle stiffness and elasticity were examined by myotonometric evaluation in adult females, and it was observed that there was a weak correlation between the UT elasticity and BMI and a moderate correlation between the SCM and UT muscle stiffness and BMI (11). In a study investigating the mechanical properties of the Achilles tendon and gastrocnemius muscle, it was stated that BMI did not affect mechanical properties (12). In a study performed using another technique, elastography, BMI was shown to be related to the upper trapezius stiffness (13), while no relationship was found between mechanical properties and BMI in other studies conducted on different muscles $(14,15)$. Previous studies were investigated general mechanical properties in healthy individual without wider BMI range. This study was planned to determine influence of body mass index on muscular mechanical properties in people with obesity.

\section{Materials And Methods}

\section{Individuals}

This study is a prospective observational study. A total of 300 individuals (mean age: $27.31 \pm 7.21$ years) were participated. Sedentary individuals without any systemic or metabolic disease, without psychological disease or drug use, without any disease that might cause muscle disease or muscle atrophy, who had not undergone musculoskeletal surgery in the last three months, with physical activity levels of $\leq 300 \mathrm{MET}$ min/week according to the international physical activity survey score were included in the study (16). Individuals with rheumatic diseases, a history of fibromyalgia, females in the menstrual cycle period and individuals with a history of pregnancy, those with diseases such as Parkinson's disease, multiple sclerosis, muscular dystrophy that might affect muscle tone 
and movements were excluded from the study. It was stated that they should not consume alcohol for at least 24 hours and not engage in strenuous physical activity for at least 48 hours before the test (17).

Individuals were divided into three subcategories according to sexes and BMI range: Group $1\left(\mathrm{BMI}=18.50-24.99 \mathrm{~kg} / \mathrm{m}^{2}\right)(\mathrm{n}=100)$, Group $2(\mathrm{BMI}=25.00-29.99$ $\left.\mathrm{kg} / \mathrm{m}^{2}\right)(\mathrm{n}=100)$, and Group $3\left(\mathrm{BMl} \geq 30 \mathrm{~kg} / \mathrm{m}^{2}\right)(\mathrm{n}=100)$.

\section{Procedures}

The ethics committee approval numbered 2020/101 and dated 16.12.2020 was obtained from the non-invasive research ethics committee of Hasan Kalyoncu University, Faculty of Health Sciences. All participants voluntarily involved and they were informed about the content and purpose of the study and signed the consent form The physical characteristics and demographic information of the individuals were recorded prior to the test. Weight was evaluated using an electronic scale GSE 450 (GSE Scale Systems, Novi, Michigan), and height was evaluated using a standard stadiometer. BMI was calculated by dividing the weight in kilograms by the square of height in meters.

The tone and viscoelastic properties of the biceps brachii (BB) and biceps femoris (BF) muscles were evaluated bilaterally using a Myoton Pro (Müomeetria Ltd., Tallinn, Estonia) device. This device is known to have good to excellent reliability in healthy individuals $(18,19)$. It can be used for objective diagnosis and monitoring in soft tissues in terms of validity and inter-user reliability $(20,21)$.

The BB mechanical properties were evaluated by palpating the lateral end of the acromion and the cubital fossa in the middle from the $3 / 4$ of the distance between them with the individual in the resting supine position (22). Concerning the BF, the individual lay in the prone position and was asked to contract the hamstring muscle after placing a pillow under the ankle. The muscle was palpated while the individual was contracting it. Along with the contraction, the most prominent part of the muscle was marked and measured in muscle contraction, as suggested by Gavronski et al. (23). These muscles were preferred since they had been studied previously in many studies (24-25). For each measurement, mean deviation, median and $95 \%$ confidence interval were given, and mean values obtained from three consecutive measurements from the reference points were used in statistical analysis.

The Myoton device provides data on three different properties. Tone (f) indicates a passive or resting muscle state without oscillation frequency ( $\mathrm{Hz}$ ), voluntary contraction (26). Stiffness ( $\mathrm{N} / \mathrm{m}$ ) indicates resistance to any contraction or external intervention (26). Elasticity (D) is obtained as a logarithmic reduction of the natural oscillation of soft tissues. The increase in the number in the measurement obtained means the decrease in elasticity and is inversely proportional (26). The measurement creates a short-duration (15 ms), low-force $(0.40 \mathrm{~N})$ mechanical stimulation that induces damped natural oscillations of the tissues after the constant pre-stimulation $(0.18 \mathrm{~N})$ of the probe placed perpendicular to the muscle ( $3 \mathrm{~mm}$ in diameter) and is obtained by recording oscillations using an accelerometer (26).

\section{Statistical Analysis}

Descriptive statistics were presented as mean \pm standard deviation. The Shapiro-Wilk test was used to check whether the data were normally distributed. The Mann-Whitney $U$ test was used to compare differences between males and females (sex), and the Kruskal-Wallis test was used to compare differences in three groups (according to BMI range) for non-normally distributed data. Post-hoc binary comparisons (after Dunn's correction) were used to determine the source of the difference. The relationship between numerical variables was evaluated by Spearman correlation. As Spearman's rank correlation coefficient, $0.00-0.10$ was interpreted as very weak correlation or no correlation, $0.10-0.39$ as weak correlation, $0.40-0.69$ as moderate correlation, $0.70-0.89$ as high correlation, and $0.90-1.00$ was interpreted as very strong correlation (27).

Statistical analysis was conducted using Windows version 24.0 for SPSS (IBM Corp. Armonk, NY IBM Corp.), and the value $p<0.05$ was considered statistically significant. The minimum total number of participants required for each group was determined to be 44 ( $a=0.01)$ in order to determine the expectation that there would be a significant difference between three different BMI groups at the large effect level $(f=0.75)$ obtained by referring to the published article with a power of 0.90. G-power program version 3.9.1.7 was used in power analysis (28).

\section{Results}

A total of 300 healthy individuals (mean age;27.31 \pm 7.21 years, mean height; $1.69 \pm 0.84 \mathrm{~m}$, mean weight; $77.86 \pm 14.48 \mathrm{~kg}$ ), including 150 females (mean age; $26.03 \pm 6.89$ years) and 150 males (mean age; $28.6 \pm 7.33$ years) were participated in this study. The 150 male participants; 50 (33.33\%) were in Group 1,50 (33.33\%) were in Group 2, and 50 (33.33\%) were in Group 3. The 150 female participants; 50 (33.33\%) were in Group 1, 50 (33.33\%) were in Group 2, and 50 (33.33\%) were in Group 3.

\section{Correlation between the BB and BF mechanical properties and BMI}

\section{All individuals}

A weak negative correlation was found between the right and left BB tone and BMI $(r=-0.177-p=0.002, r=-0.157-p=0.006$, respectively). A weak positive correlation was revealed between the right and left BB elasticity and BMI $(r=0.258-p=0.000, r=0.211-p=0.000$, respectively). No correlation was determined in the bilateral BB stiffness $(p>0.05)$. A weak positive correlation was found between the left BF stiffness and tone and BMI $(r=0.164-p=0.004, r=0.143-p=$ 0.013 , respectively). No correlation was detected in other mechanical parameters of the BF $(p>0.05)($ Table 1$)$. 
Table 1

The Relationship Between the Mechanical Properties and BMI

\begin{tabular}{|c|c|c|c|c|}
\hline & & Total $(n=300)$ & Males $(n=150)$ & Females $(n=150)$ \\
\hline \multirow[t]{2}{*}{ Right BB Tone (Hz) } & r & $-0.177^{\star}$ & -0.147 & $-0.212^{\star}$ \\
\hline & $\mathrm{p}$ & 0.002 & 0.072 & 0.009 \\
\hline \multirow[t]{2}{*}{ Right BB Stiffness (N/m) } & $r$ & 0.066 & 0.125 & 0.020 \\
\hline & $\mathrm{p}$ & 0.254 & 0.128 & 0.810 \\
\hline \multirow[t]{2}{*}{ Right BB Elasticity (log) } & $\mathrm{r}$ & $0.258^{*}$ & $0.285^{*}$ & $0.234^{*}$ \\
\hline & $\mathrm{p}$ & 0.000 & 0.000 & 0.004 \\
\hline \multirow[t]{2}{*}{ Left BB Tone (Hz) } & $\mathrm{r}$ & $-0.157^{*}$ & -0.131 & $-0.180^{*}$ \\
\hline & $\mathrm{p}$ & 0.006 & 0.110 & 0.027 \\
\hline \multirow[t]{2}{*}{ Left BB Stiffness (N/m) } & $r$ & 0.036 & 0.079 & -0.001 \\
\hline & $\mathrm{p}$ & 0.538 & 0.338 & 0.993 \\
\hline \multirow[t]{2}{*}{ Left BB Elasticity (log) } & r & $0.211^{*}$ & $0.199^{*}$ & $0.223^{*}$ \\
\hline & $\mathrm{p}$ & 0.000 & 0.015 & 0.006 \\
\hline \multirow[t]{2}{*}{ Right BF Tone (Hz) } & $r$ & 0.105 & 0.114 & 0.103 \\
\hline & $\mathrm{p}$ & 0.069 & 0.164 & 0.209 \\
\hline \multirow[t]{2}{*}{ Right BF Stiffness (N/m) } & $\mathrm{r}$ & 0.108 & 0,134 & 0.111 \\
\hline & $\mathrm{p}$ & 0.061 & 0.103 & 0.175 \\
\hline \multirow[t]{2}{*}{ Right BF Elasticity (log) } & $r$ & 0.104 & 0.141 & 0.096 \\
\hline & $\mathrm{p}$ & 0.072 & 0.086 & 0.241 \\
\hline \multirow[t]{2}{*}{ Left BF Tone (Hz) } & $\mathrm{r}$ & $0.143^{*}$ & $0.301^{*}$ & 0.071 \\
\hline & $\mathrm{p}$ & 0.013 & 0.000 & 0.390 \\
\hline \multirow[t]{2}{*}{ Left BF Stiffness (N/m) } & $\mathrm{r}$ & $0.164^{*}$ & $0.284^{*}$ & 0.123 \\
\hline & $\mathrm{p}$ & 0.004 & 0.000 & 0.133 \\
\hline \multirow[t]{2}{*}{ Left BF Elasticity (log) } & $r$ & 0.090 & 0.096 & 0.105 \\
\hline & $p$ & 0.121 & 0.244 & 0.202 \\
\hline
\end{tabular}

\section{Females}

A weak positive correlation was found between the right and left BB elasticity and BMI ( $r=0.234-p=0.004, r=-0.223-p=0.006$, respectively), and a weak negative correlation was revealed with the right and left BB tone $(r=-0.212-p=0.009, r=-0.180-p=0.027$, respectively). No correlation was detected in the other mechanical properties of the BB and BF $(p>0.05)$ (Table 1).

\section{Males}

A weak positive correlation was revealed between the right and left BB elasticity and BMI $(r=0.285-p=0.000, r=0.199-p=0.015)$. No correlation was found in the other parameters of the BB $(p>0.05)$.

A weak positive correlation was observed with the left BF stiffness and tone $(r=0.284-p=0.000, r=0.301-p=0.000$, respectively). No correlation was found between the bilateral BF elasticity and BMI $(p>0.05)$ (Table 1).

\section{Comparison Of Mechanical Properties In Bmi Groups}

\section{All individuals}

A statistical difference was found in all mechanical properties of the right and left BB muscle, left BF tone and stiffness ( $<<0.05)($ Table 2$)$. When advanced statistical methods were used, it was observed that the bilateral BB tone in Group 3 was lower than the other two groups ( $p<0.05)$. The right BB stiffness of 
Group 2 was found to be higher compared to the other two groups $(p<0.05)$. While the right and left BB elasticity was similar in Groups 2 and 3 , and it was higher than Group $1(p<0.05)$. The left BF tone and stiffness of Group 3 were found to be significantly higher than Groups 1 and 2 ( $p<0.05)($ Table 3 ).

Table 2

The comparison of mechanical properties in BMI groups

\begin{tabular}{|c|c|c|c|c|c|c|c|c|c|c|c|c|}
\hline & Group 1 & & & Group 2 & & Grol & & & $p$ & & & \\
\hline Right & $\begin{array}{l}T(n= \\
100)\end{array}$ & $\begin{array}{l}M(n= \\
50)\end{array}$ & $F(n=50)$ & $\begin{array}{l}T(n= \\
100)\end{array}$ & $\begin{array}{l}M(n= \\
50)\end{array}$ & $F(n=50)$ & $\begin{array}{l}T(n= \\
100)\end{array}$ & $\begin{array}{l}M(n= \\
50)\end{array}$ & $F(n=50)$ & $\mathrm{T}$ & $M$ & $\mathrm{~F}$ \\
\hline $\begin{array}{l}\text { BB Tone } \\
(\mathrm{Hz})\end{array}$ & $\begin{array}{l}14.32 \pm \\
1.72\end{array}$ & $\begin{array}{l}14.5 \pm \\
1.85\end{array}$ & $\begin{array}{l}14.13 \pm \\
1.57\end{array}$ & $\begin{array}{l}14.4 \pm \\
2.44\end{array}$ & $\begin{array}{l}15.08 \pm \\
2.94\end{array}$ & $\begin{array}{l}13.73 \pm \\
1.59\end{array}$ & $\begin{array}{l}13.61 \pm \\
1.35\end{array}$ & $\begin{array}{l}13.85 \pm \\
1.19\end{array}$ & $\begin{array}{l}13.36 \pm \\
1.46\end{array}$ & 0.006 & 0.019 & 0.051 \\
\hline $\begin{array}{l}\text { BB } \\
\text { Stiffness } \\
(\mathrm{N} / \mathrm{m})\end{array}$ & $\begin{array}{l}215.22 \pm \\
42.49\end{array}$ & $\begin{array}{l}211.9 \pm \\
48.08\end{array}$ & $\begin{array}{l}218.54 \pm \\
36.24\end{array}$ & $\begin{array}{l}235.41 \pm \\
48.8\end{array}$ & $\begin{array}{l}242.16 \pm \\
58.06\end{array}$ & $\begin{array}{l}228.66 \pm \\
36.72\end{array}$ & $\begin{array}{l}218.29 \pm \\
34.14\end{array}$ & $\begin{array}{l}216.64 \pm \\
32.35\end{array}$ & $\begin{array}{l}219.94 \pm \\
36.09\end{array}$ & 0.001 & 0.001 & 0.214 \\
\hline $\begin{array}{l}\text { BB Elast. } \\
\text { (log) }\end{array}$ & $\begin{array}{l}1.00 \pm \\
0.22\end{array}$ & $\begin{array}{l}0.97 \pm \\
0.2\end{array}$ & $\begin{array}{l}1.04 \pm \\
0.14\end{array}$ & $\begin{array}{l}1.13 \pm \\
0.24\end{array}$ & $\begin{array}{l}1.08 \pm \\
0.22\end{array}$ & $\begin{array}{l}1.18 \pm \\
0.25\end{array}$ & $\begin{array}{l}1.13 \pm \\
0.26\end{array}$ & $\begin{array}{l}1.09 \pm \\
0.28\end{array}$ & $\begin{array}{l}1.17 \pm \\
0.22\end{array}$ & 0.001 & 0.010 & 0.007 \\
\hline $\begin{array}{l}\text { BF Tone } \\
(\mathrm{Hz})\end{array}$ & $\begin{array}{l}15.01 \pm \\
2.13\end{array}$ & $\begin{array}{l}15.81 \pm \\
1.87\end{array}$ & $\begin{array}{l}14.21 \pm \\
2.09\end{array}$ & $\begin{array}{l}15.66 \pm \\
2.25\end{array}$ & $\begin{array}{l}16.79 \pm \\
2.24\end{array}$ & $\begin{array}{l}14.53 \pm \\
1.59\end{array}$ & $\begin{array}{l}15.45 \pm \\
2.16\end{array}$ & $\begin{array}{l}16.31 \pm \\
1.83\end{array}$ & $\begin{array}{l}14.58 \pm \\
2.14\end{array}$ & 0.138 & 0.065 & 0.427 \\
\hline $\begin{array}{l}\text { BF } \\
\text { Stiffness } \\
(\mathrm{N} / \mathrm{m})\end{array}$ & $\begin{array}{l}243.08 \pm \\
53.4\end{array}$ & $\begin{array}{l}258.5 \pm \\
48.14\end{array}$ & $\begin{array}{l}227.66 \pm \\
54.39\end{array}$ & $\begin{array}{l}260.57 \pm \\
57.55\end{array}$ & $\begin{array}{l}289.62 \pm \\
60.51\end{array}$ & $\begin{array}{l}231.52 \pm \\
36.17\end{array}$ & $\begin{array}{l}258.23 \pm \\
59.85\end{array}$ & $\begin{array}{l}278 \pm \\
63.87\end{array}$ & $\begin{array}{l}238.46 \pm \\
48.57\end{array}$ & 0.090 & 0.031 & 0.345 \\
\hline $\begin{array}{l}\text { BF Elast. } \\
\text { (log) }\end{array}$ & $\begin{array}{l}1.09 \pm \\
0.25\end{array}$ & $\begin{array}{l}1.19 \pm \\
0.23\end{array}$ & $1 \pm 0.24$ & $\begin{array}{l}1.1 \pm \\
0.27\end{array}$ & $\begin{array}{l}1.21 \pm \\
0.3\end{array}$ & $\begin{array}{l}1.00 \pm \\
0.18\end{array}$ & $\begin{array}{l}1.15 \pm \\
0.27\end{array}$ & $\begin{array}{l}1.24 \pm \\
0.25\end{array}$ & $\begin{array}{l}1.07 \pm \\
0.26\end{array}$ & 0.175 & 0.493 & 0.335 \\
\hline \multicolumn{13}{|l|}{ Left } \\
\hline $\begin{array}{l}\text { BF Tone } \\
(\mathrm{Hz})\end{array}$ & $\begin{array}{l}14.89 \pm \\
1.98\end{array}$ & $\begin{array}{l}15.45 \pm \\
1.36\end{array}$ & $\begin{array}{l}14.32 \pm \\
2.32\end{array}$ & $\begin{array}{l}15.42 \pm \\
2.04\end{array}$ & $\begin{array}{l}16.28 \pm \\
1.9\end{array}$ & $\begin{array}{l}14.57 \pm \\
1.83\end{array}$ & $\begin{array}{l}15.8 \pm \\
2.56\end{array}$ & $\begin{array}{l}16.99 \pm \\
2.36\end{array}$ & $\begin{array}{l}14.60 \pm \\
2.18\end{array}$ & 0.049 & 0.003 & 0.562 \\
\hline $\begin{array}{l}\text { BF } \\
\text { Stiffness } \\
(\mathrm{N} / \mathrm{m})\end{array}$ & $\begin{array}{l}242.38 \pm \\
50.69\end{array}$ & $\begin{array}{l}254.12 \pm \\
37.54\end{array}$ & $\begin{array}{l}230.64 \pm \\
59.17\end{array}$ & $\begin{array}{l}261.01 \pm \\
50.05\end{array}$ & $\begin{array}{l}286.04 \pm \\
45.95\end{array}$ & $\begin{array}{l}235.98 \pm \\
40.88\end{array}$ & $\begin{array}{l}267 \pm \\
56.46\end{array}$ & $\begin{array}{l}288.34 \pm \\
52.35\end{array}$ & $\begin{array}{l}245.66 \pm \\
52.63\end{array}$ & 0.005 & 0.001 & 0.215 \\
\hline $\begin{array}{l}\text { BF Elast. } \\
(\log )\end{array}$ & $\begin{array}{l}1.14 \pm \\
0.24\end{array}$ & $\begin{array}{l}1.26 \pm \\
0.24\end{array}$ & $\begin{array}{l}1.03 \pm \\
0.18\end{array}$ & $\begin{array}{l}1.12 \pm \\
0.26\end{array}$ & $\begin{array}{l}1.22 \pm \\
0.28\end{array}$ & $\begin{array}{l}1.03 \pm \\
0.20\end{array}$ & $\begin{array}{l}1.13 \pm \\
0.27\end{array}$ & $\begin{array}{l}1.3 \pm \\
0.27\end{array}$ & $\begin{array}{l}1.08 \pm \\
0.23\end{array}$ & 0.053 & 0.127 & 0.225 \\
\hline $\begin{array}{l}\text { BB Tone } \\
(\mathrm{Hz})\end{array}$ & $\begin{array}{l}14.43 \pm \\
1.84\end{array}$ & $\begin{array}{l}14.8 \pm \\
1.9\end{array}$ & $\begin{array}{l}14.06 \pm \\
1.72\end{array}$ & $\begin{array}{l}14.14 \pm \\
1.7\end{array}$ & $\begin{array}{l}14.39 \pm \\
1.79\end{array}$ & $\begin{array}{l}13.89 \pm \\
1.59\end{array}$ & $\begin{array}{l}14.13 \pm \\
1.68\end{array}$ & $\begin{array}{l}14.17 \pm \\
1.55\end{array}$ & $\begin{array}{l}13.5 \pm \\
1.46\end{array}$ & 0.037 & 0.238 & 0.140 \\
\hline $\begin{array}{l}\text { BB } \\
\text { Stiffness } \\
(\mathrm{N} / \mathrm{m})\end{array}$ & $\begin{array}{l}221.89 \pm \\
45.81\end{array}$ & $\begin{array}{l}218.66 \pm \\
48.9\end{array}$ & $\begin{array}{l}225.12 \pm \\
42.74\end{array}$ & $\begin{array}{l}229.64 \pm \\
43.25\end{array}$ & $\begin{array}{l}231.04 \pm \\
46.74\end{array}$ & $\begin{array}{l}228.24 \pm \\
39.88\end{array}$ & $\begin{array}{l}229.16 \pm \\
42.81\end{array}$ & $\begin{array}{l}221.04 \pm \\
36.89\end{array}$ & $\begin{array}{l}225.44 \pm \\
35.45\end{array}$ & 0.040 & 0.036 & 0.622 \\
\hline $\begin{array}{l}\text { BB Elast. } \\
(\log )\end{array}$ & $\begin{array}{l}1.04 \pm \\
0.25\end{array}$ & $\begin{array}{l}0.99 \pm \\
0.24\end{array}$ & $\begin{array}{l}1.08 \pm \\
0.26\end{array}$ & $\begin{array}{l}1.12 \pm \\
0.27\end{array}$ & $\begin{array}{l}1.1 \pm \\
0.31\end{array}$ & $\begin{array}{l}1.15 \pm \\
0.21\end{array}$ & $\begin{array}{l}1.12 \pm \\
0.26\end{array}$ & $\begin{array}{l}1.13 \pm \\
0.29\end{array}$ & $\begin{array}{l}1.23 \pm \\
0.28\end{array}$ & 0.001 & 0.044 & 0.033 \\
\hline
\end{tabular}

p < 0.05. Abbreviations: T: Total, M: Male, F: Female, BB: biceps brachii, BF: biceps femoris, Hz: Frequency, N/m: newton/meter, log: logarithmic reduction

Table 3

Dunn's multiple comparison test results

\begin{tabular}{|c|c|c|c|c|c|c|c|c|c|c|c|c|c|}
\hline & All partic & ipants & & & & & & & Males & & & & \\
\hline & $\begin{array}{l}\text { Right } \\
\text { BB } \\
\text { Tone }\end{array}$ & $\begin{array}{l}\text { Right BB } \\
\text { Stiffness }\end{array}$ & $\begin{array}{l}\text { Right BB } \\
\text { Elasticity }\end{array}$ & $\begin{array}{l}\text { Left } \\
\text { BB } \\
\text { Tone }\end{array}$ & $\begin{array}{l}\text { Left BB } \\
\text { Stiffness }\end{array}$ & $\begin{array}{l}\text { Left BB } \\
\text { Elasticity }\end{array}$ & $\begin{array}{l}\text { Left } \\
\text { BF } \\
\text { Tonus }\end{array}$ & $\begin{array}{l}\text { Left BF } \\
\text { Stiffness }\end{array}$ & $\begin{array}{l}\text { Right } \\
\text { BB } \\
\text { Tone }\end{array}$ & $\begin{array}{l}\text { Right BB } \\
\text { Stiffness }\end{array}$ & $\begin{array}{l}\text { Right BB } \\
\text { Elasticity }\end{array}$ & $\begin{array}{l}\text { Left BB } \\
\text { Stiffness }\end{array}$ & $\begin{array}{l}\text { Left BI } \\
\text { Elastic }\end{array}$ \\
\hline BMI & $P$ & $\mathbf{P}$ & $\mathbf{P}$ & $\mathbf{P}$ & $\mathbf{P}$ & $\mathbf{P}$ & $\mathbf{P}$ & $\mathbf{P}$ & $P$ & $P$ & $\mathbf{P}$ & $\mathbf{P}$ & $P$ \\
\hline $\begin{array}{l}\text { Group } \\
2-3\end{array}$ & $0.006 *$ & $0.005^{*}$ & 0.808 & 0.116 & 0.074 & 0.157 & 0.554 & 0.733 & $0.005^{*}$ & $0.011 *$ & 0.754 & 0.089 & 0.392 \\
\hline $\begin{array}{l}\text { Group } \\
1-3\end{array}$ & $0.006^{*}$ & 0.197 & $0.001 *$ & $0.011 *$ & 0.506 & $0.001 *$ & $0.018^{*}$ & $0.003^{*}$ & 0.135 & 0.119 & $0.005^{*}$ & 0.409 & $0.014^{*}$ \\
\hline $\begin{array}{l}\text { Group } \\
1-2\end{array}$ & 0.994 & $0.001 *$ & $0.001 *$ & 0.328 & $0.014^{*}$ & $0.026 *$ & 0.076 & $0.008 *$ & 0.184 & $0.001 *$ & $0.013^{*}$ & $0.012^{*}$ & 0.108 \\
\hline
\end{tabular}

* $\mathrm{p}<0.05$. Abbreviations: BB: biceps brachii, BF: biceps femoris, BMI: Body mass index

\section{Males}

The statistical differences were found in the right BB all mechanical properties (stiffness, tone, elasticity) and the right BF stiffness, left BB stiffness and elasticity, left BF tone and stiffness base on BMI group comparasion $(p<0.05)$ (Table 2). The right BB tone of Group 3 was found to be lower than the other

Page 5/9 
two groups $(p<0.05)$. The right and left BB stiffness of Group 2 was determined to be higher than that of Groups 1 and 3 ( $p<0.05)$. The left BF tone of Group 3 was higher than that of Group 1 and Group $2(p<0.05)$. The right and left BF stiffness increased as BMI increased, and it was found to be higher in Group 2 than Group $1(p<0.05)$. The right and left BB elasticity in Group 1 was higher then other two groups $(p<0.05)($ Table 3).

\section{Females}

The statistical differences were found in the right and left BB elasticity $(p<0.05)$ (Table 2). The right BB elasticity was higher in Group 1 compared to the other groups $(p<0.05)$, the BB elasticity in Group 2 was better than in Group 3, but it was not statistically significant in Groups 2 and 3 ( $p>0.05$ ). Although the left BB elasticity was higher in Group 1 compared to the other groups $(p<0.05)$, no statistical difference was found between Group 1-2 and Group 2-3 ( $p>0.05$ ) (Table 3).

\section{Discussion}

This study was conducted to determine influence of body mass index on muscular mechanical properties in people with obesity. There was found a weak relation between $\mathrm{BMI}$ and the mechanical properties of the BB and BF muscles. The bilateral BB tone and elasticity decreased as BMI increased, and the left BF stiffness increased. Different mechanical properties were observed in sex comprasion base on BMI clasification. The BB and BF mechanical properties were affected more in males than females.

Resting muscle tone is classified into two categories as neural and non-neural. If there is no neural activation, muscle tone contains passive stiffness and viscoelastic properties (22). When all individuals were examined, a weak negative correlation was observed between BMI and the bilateral BB tone. The left BF tone showed a positive correlation. While the left BF tone was positively correlated in males, the bilateral BB tone was found to be weakly negatively correlated in females. This correlation in tone suggests that it is caused by different neural and muscular adaptations that people with obesity can develop in the lower extremity and upper extremity. In a study conducted with 12 people with obesity (BMI > 27) adolescent girls and 12 healthy girls, it was reported that with increased mechanical load in people with obesity, adaptation would occur in muscles and nerves, and as a result, people with obesity might have a larger pennation angle, anatomical cross-sectional area and muscle thickness (29). While this advantage in mechanical loading is observed in the positive direction in the lower extremity depending on the increase in weight, it may explain that it is in the negative direction in the upper extremity. The upper extremity, which lacks mechanical loading, and the reduced inactivity, may bring along a disadvantage that will result in the loss of the cross-sectional area and contractile components. In studies comparing athletes and sedentary individuals, it is stated that sedentary individuals have a smaller cross-sectional area (30). This opposing relationship proves that muscular and neural structures will develop different adaptations in the upper and lower extremities.

In the evaluations we performed in males and females, the right and left BB elasticity showed a similar weak positive correlation in all three groups. In the study in which Kocur et al. evaluated the relationship between the SCM muscle stiffness and elasticity and BMI, it was indicated to be highly correlated with elasticity and moderately correlated with stiffness (31). In a study comparing mechanical properties, it was reported that males with high BMI had lower biceps brachii elasticity than females (28). Interestingly, in our findings, a weak correlation with the bilateral BB elasticity in the upper extremity in all three groups (all individuals, males and females) was not observed in the bilateral BF elasticity in the lower extremity. Furthermore, no correlation was observed in the bilateral BB stiffness. A weak positive correlation was found between the left BF stiffness and BMI only in males. Fat infiltration into skeletal muscles in people with obesity can create higher muscle stiffness and reduce flexibility compared to the people with non-obesity group due to the limitation of range of motion and stable posture (28). Moreover, the increase in adipokines, which regulate the production of metalloproteinases, prostanoids, and cytokines in adipose tissue, can affect stiffness and flexibility in overweight and people with obesity (32). The different elasticity relationship in the lower and upper extremities suggests that it may be caused by changes in adipose tissue according to sex.

When all individuals were compared in the sub-groups according to BMI, decreased bilateral BB tone and elasticity were found in individuals who were firstdegree people with obesity (Group 3). The right BB and left BF stiffness of overweight (Group 2) and first-degree people with obesity (Group 3) individuals was higher compared to normal and underweight individuals. Comparisons in males were close to the characteristics we obtained from all the individuals above, while in females, mechanical properties were not affected, except for the bilateral BB elasticity. Along with excessive weight gain, adipocyte hypertrophy, intramuscular adipose tissue infiltration, an increase in fibrous components (a decrease in contractile elements), a decrease in the size and number of muscle fibers can be said to be the causes of decreased elasticity and increased stiffness (33-35). However, at this point, we think that adaptations that develop in daily life according to the mechanical loads on the lower and upper extremities will be the primary cause. Increased BMI can affect stability and may provide a biomechanical advantage by increasing the stiffness and tone of the lower extremity muscles due to excessive trunk oscillations in stance or walking.

An inverse correlation between muscle tone and subcutaneous fat was previously observed in a study on sedentary individuals (22). Therefore, it can be assumed that more thickness of subcutaneous fat may alter the response of muscles, reduce their oscillation and frequency, and thus affect tone. In a study comparing female athletes with sedentary females, it was stated that athletes had low BMI values, which was the reason for the decrease in the percentage of subcutaneous fat and the high muscle tone found (30). The calculation of BMI using height and weight in our study may have limited our study in terms of not measuring subcutaneous fat tissue thickness. At this point, we think that regional fat deposition together with BMI may be important for future studies.

From a practical point of view, the increased tone and muscle stiffness in relation to BMI may lead to a decrease in the risk of falls, injury and overall muscular performance, resulting in a limitation in the ability to perform daily activities (36). In this study, increased BMI changes the mechanical properties of the muscles. The decrease in the muscular performance of people with obesity may indicate why physical activity is reduced or vice versa.

\section{Limitations}


Our study provides important information for influencing BMI on the musculoskeletal system. But we had some limitations. Firstly, we used the classical BMI calculation using only height and weight, and we did not evaluate the adipose tissue thickness of the individuals. We could have obtained clearer findings with the thought that there might be individuals with different body compositions. If we could have evaluated whether the muscles were relaxed sufficiently in the resting position by an objective method such as EMG, it could help us better understand the mechanical properties, especially the tone. As it is, the findings of our study will help further investigate the relationship between obesity and the mechanical properties of the musculoskeletal system.

\section{Conclusion}

A weak correlation was found between BMI and the mechanical properties of the BB and BF muscles. The bilateral BB tone and elasticity decreased as BMI increased, and the left BF stiffness increased. Different mechanical properties were observed in sex comprasion base on BMI clasification. The BB and BF mechanical properties were affected more in males than females. In addition to excess weight, increased stiffness and decreased elasticity may have adverse effects on other systems, especially physical activity, ambulation, and musculoskeletal system.

\section{Declarations}

\section{Acknowledgements}

The authors would like to thank all participants in this study.

\section{Ethical approval}

This study was approved by the Ethics Committee for Non-Invasive Research Studies of Hasan Kalyoncu University Faculty of Health Sciences (approval number 2020/101).

\section{Informed consent}

Informed writing consent was obtained from each participants before starting study

\section{Clinical Registry}

NCT04721431, 20 January 2021, https://clinicaltrials.gov/ct2/show/NCT04721431

\section{Author Contributions}

S.U: conception and design, data analysis, manuscript editing and final approval of manuscript, revised the manuscript for intellectual content,

E.R: literature search, data collection and analysis, writing manuscript

YY: statistical analysis, critical review of manuscript,

\section{Conflict of interest}

All authors declare that they have no conflict of interest.

\section{Funding}

No funded

\section{Data Availability}

Not applicable.

\section{References}

1. Flegal KM, Carroll MD, Kit BK, Ogden CL. Prevalence of obesity and trends in the distribution of body mass index among US adults, $1999-2010$. JAMA 2012;307(5):491-497.

2. Costa-Urrutia P, Vizuet-Gámez A, Ramirez-Alcántara M, Guillen-González MÁ, Medina-Contreras O, Valdes-Moreno M, et al. Obesity measured as percent body fat, relationship with body mass index, and percentile curves for Mexican pediatric population. PloS one2019;14(2):e0212792.

3. Weir CB, Jan A. BMI classification percentile and cut off points. 2019; StatPearls.

4. Chen LJ, Fox KR, Haase A, Wang JM. Obesity, fitness and health in Taiwanese children and adolescents. Eur J Clin Nutr 2006;60(12):1367-1375.

5. Wang F, McDonald T, Champagne LJ, Edington DW. Relationship of body mass index and physical activity to health care costs among employees. $J$ Occup Environ Med 2004;46(5):428-436.

6. Hamaguchi Y, Kaido T, Okumura S, Kobayashi A, Shirai H, Yagi S, et al. Impact of skeletal muscle mass index, intramuscular adipose tissue content, and visceral to subcutaneous adipose tissue area ratio on early mortality of living donor liver ransplantation. Transplantation 2017;101(3):565-574.

7. Šarabon N, Kozinc Ž, Podrekar N. Using shear-wave elastography in skeletal muscle: A repeatability and reproducibility study on biceps femoris muscle. Plos one 2019;14(8):e0222008. 
8. Feng YN, Li YP, Liu CL, Zhang ZJ. Assessing the elastic properties of skeletal muscle and tendon using shearwave ultrasound elastography and MyotonPRO. Sci Rep2018;8(1): 1-9.

9. Gapeyeva H, Vain A. Methodical guide: principles of applying Myoton in physical medicine and rehabilitation. Tartu, Estonia: Müomeetria Ltd. 2008.

10. Agyapong-Badu S, Warner M, Samuel D, Stokes M. Practical Considerations for Standardized Recording of Muscle Mechanical Properties Using a Myometric Device: recording Site, Muscle Length, State of Contraction and Prior Activity. J Musculoskelet Res 2018;21(02):1850010.

11. Kocur P, Tomczak M, Wiernicka M, Goliwąs M, Lewandowski J, Łochyński D. Relationship between age, BMI, head posture and superficial neck muscle stiffness and elasticity in adult women. Sci Rep 2019;9(1):1-10.

12. Ericson Morgan G, Martin R, Welch H, Morris K. Quantitative Weight Bearing and non-weight Bearing Measures of Stiffness in the Achilles Tendon and Gastrocnemius Muscle. Edra. 2020, March.

13. Kuo WH, Jian DW, Wang TG, Wang YC. Neck muscle stiffness quantified by sonoelastography is correlated with body mass index and chronic neck pain symptoms. Ultrasound Med Biol 2013;39(8):1356-1361.

14. Seo A, Lee JH, Kusaka Y. Estimation of trunk muscle parameters for a biomechanical model by age, height and weight. J Occup Health 2003;45(4):197201.

15. Wood S, Pearsall DJ, Ross R, Reid JG. Trunk muscle parameters determined from MRI for lean to obese males. Clin Bio 1996;11(3):139-144.

16. Saris WHM, Blair SN, Van Baak MA, Eaton SB, Davies PSW, Di Pietro L, et al. How much physical activity is enough to prevent unhealthy weight gain? Outcome of the IASO 1st Stock Conference and consensus statement. Obes Rev 2003;4(2):101-114.

17. Agyapong-Badu S, Aird L, Bailey L, Mooney K, Mullix J, Warner M, et al. Interrater reliability of muscle tone, stiffness and elasticity measurements of rectus femoris and biceps brachii in healthy young and older males. Work Papers Health Sci 2013;4:1-11.

18. Bailey L, Samuel D, Warner MB, Stokes M. Parameters representing muscle tone, elasticity and stiffness of biceps brachii in healthy older males: symmetry and within-session reliability using the MyotonPRO. J Neurol Disord 2013;1(1):1-7.

19. Zinder SM, Padua DA. Reliability, validity, and precision of a handheld myometer for assessing in vivo muscle stiffness. J Sport Rehabil 2011 ; e-pub ahead of printig Agust 2011; doi: 10.1123/jsr.2010-0051

20. Schneebeli A, Falla D, Clijsen R, Barbero M. Myotonometry for the evaluation of Achilles tendon mechanical properties: a reliability and construct validity study. BMJ Open Sport Exerc Med 2020;e-pub; dx.doi.org/10.1136/bmjsem-2019-000726

21. Liu CL, Li YP, Wang XQ, Zhang ZJ. Quantifying the stiffness of achilles tendon: Intra-and inter-operator reliability and the effect of ankle joint motion. Med Sci Mon Int Med J Exp Clin Res 2018;24:4876.

22. Agyapong-Badu S, Warner M, Samuel D, Stokes M. Measurement of ageing effects on muscle tone and mechanical properties of rectus femoris and biceps brachii in healthy males and females using a novel hand-held myometric device. Arch Gerontol Geriatr 2016;62:59-67.

23. Gavronski G, Veraksitš A, Vasar E, Maaroos J. Evaluation of viscoelastic parameters of the skeletal muscles in junior triathletes. Physiol Meas 2007;28(6):625.

24. Rihvk I, Clough A, Clough P. Investigation to compare static stretching and proprioceptive neuromuscular facilitation contract-relax stretching effects on the visco-elastic parameters of the biceps femoris muscle. Int Musculoskelet Med 2010;32(4):157-162.

25. Colomar J, Baiget E, Corbi F. Influence of Strength, Power, and Muscular Stiffness on Stroke Velocity in Junior Tennis Players. Front Physio/ 2020;11:196.

26. Myoton. https://www.myoton.com/technology/ Updated February 14, 2021.

27. Schober P, Boer C, Schwarte LA. Correlation coefficients: appropriate use and interpretation. Anesth Analg 2018;126(5): 1763-1768.

28. Faria A, Gabriel R, Abrantes J, Brás R, Moreira H. Triceps-surae musculotendinous stiffness: relative differences between obese and non-obese postmenopausal women. Clin Bio 2009;24(10):866-871.

29. Garcia-Vicencio S, Coudeyre E, Kluka V, Cardenoux C, Jegu AG, Fourot AV, et al. The bigger, the stronger? Insights from muscle architecture and nervous characteristics in obese adolescent girls. Int J Obes 2016;40(2):245-251.

30. Gervasi M, Sisti D, Amatori S, Andreazza M, Benelli P, Sestili P, et al. Muscular viscoelastic characteristics of athletes participating in the European Master Indoor Athletics Championship. Eur J Appl Physiol 2017;117(8):1739-1746.

31. Kocur P, Grzeskowiak M, Wiernicka M, Goliwas M, Lewandowski J, Łochyński D. Effects of aging on mechanical properties of sternocleidomastoid and trapezius muscles during transition from lying to sitting position-A cross-sectional study. Arch Gerontol Geriatr 2017;70:14-18.

32. Brady AO, Straight CR, Schmidt MD, Evans EM. Impact of body mass index on the relationship between muscle quality and physical function in older women. The journal of nutrition, health \& aging 2014;18(4):378-382.

33. Sun K, Park J, Gupta OT, Holland WL, Auerbach P, Zhang N, et al. Endotrophin triggers adipose tissue fibrosis and metabolic dysfunction. Nat Commun 2014;5(1):1-12.

34. Taş S, Yılmaz S, Onur MR, Soylu AR, Altuntaş O, Korkusuz F. Patellar tendon mechanical properties change with gender, body mass index and quadriceps femoris muscle strength. Acta Orthop Traumatol Turc 2017;51(1):54-59.

35. Ramazanoğlu E, Usgu S, Yakut Y. Assessment of the mechanical characteristics of the lower extremity muscles with myotonometric measurements in healthy individuals. Physiother Q 2020;28(4):1-12.

36. Barbat-Artigas S, Pion CH, Leduc-Gaudet JP, Rolland Y, Aubertin-Leheudre M. Exploring the role of muscle mass, obesity, and age in the relationship between muscle quality and physical function. J Am Med Dir Assoc 2014;15(4):303-e13.

\section{Figures}

Page $8 / 9$ 


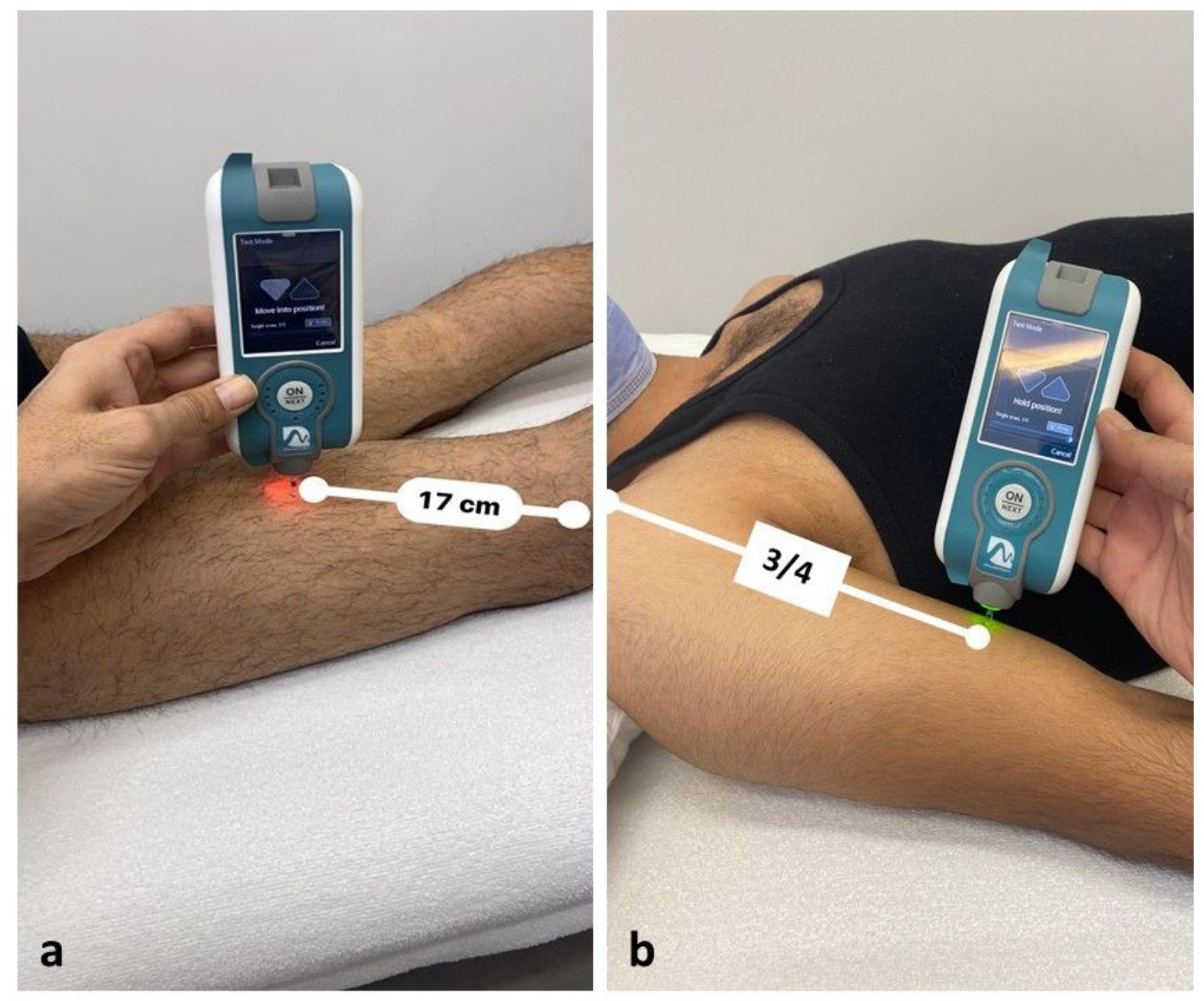

\section{Figure 1}

The reference points of muscles for myotonometric assessment. (a) Biceps Femoris, (b) Biceps Brachii. 